\title{
FRA FRELSE TIL HELSE
}

\section{Sundhedsapostlen J.P. Müllers religiøst inspirerede sundhedsdyrkelse}

\author{
HANS BONDE
}

Ved I ikke, at jeres legeme er et tempel for Helligånden, som er $i$ jer, og som I har fra Gud? (Paulus, 1 Kor 6,19)

ENGLISH ABSTRACT: The best known Danish amateur athlete in the 1890s and with his fitness program 'My System' from 1904 world-famous Danish hygienist, J.P. Muller, is the son of a priest and theologically educated. In early modernity, it is difficult to simply relinquish one's religious feelings and surrender to the modern worldview. The term 'double Christianity' covers a tendency for Christian-inspired heritage to diffuse outside the church and continue in modern forms. J.P. Muller's gymnastics and hygiene offered the people around 1900 to continue to practice asceticism and purification, but now no longer with a view to salvation in the hereafter, but to a disease-free and vital life in the worldly domain with the prospect of being at least 150 years old. Health becomes the road to salvation.

DANSK RESUME: Den bedst kendte danske amatørsportsmand i 1890'erne og med sit fitnessprogram Mit System fra 1904 verdensberømte danske hygiejniker, J.P. Müller, er præstesøn og teologisk skolet. I den tidlige modernitet er det svært gnidningsløst blot at aflægge sine religiøse følelser og overgive sig til den moderne verdensanskuelse. Begrebet 'den dobbelte kristendom' dækker over en tendens til, at kristent inspireret arvegods diffunderer uden for kirken og videreføres $i$ moderne former. Via J.P. Müllers gymnastik og hygiejne tilbydes mennesker omkring år 1900 fortsat at udøve en askese og renselse, men nu ikke langere med henblik på frelse $i$ det hinsidige, men på et sygdomsfrit og vitalt liv $i$ det dennesidige med udsigt til at kunne blive mindst 150 àr gamle. Helse bliver vejen til frelse.

KEYWORDS: Sport; Peter Sloterdijk; asceticism health hygiene gymnastics; fitness.

I den kristne tradition har der især fra middelalderen og frem udviklet sig et skarpt skel mellem det åndelige og det legemlige. Hovedpersonen i nærværende artikel - 
den verdenskendte danske gymnastikpædagog og præstesøn J.P. Müller (1866-1938) - fremhæver i 1908, at den kristne tradition for at adskille sjæl og legeme er fortsat ind i moderniteten i nye former:

Hos antikkens filosoffer og æstetikere rangerede legemet akkurat lige så højt som ånden, fordi krop og sjæl blot opfattedes som to sider af et naturligt hele ... Men vore dages "åndsaristokrater", fritænkerne, digterne og til dels videnskabsmændene har ikke kunnet emancipere sig fra den "kristelige" kulturs ensidige åndsdyrkelse. Ret betegnende er det i så henseende, at man i hine tider om et dårligt oplært individ sagde: "Han har hverken lært at læse eller svømme", mens det nu om stunder hedder "Han kan hverken læse eller skrive" (Müller 1908, 282). ${ }^{1}$

I det følgende er hovedtesen, at J.P. Müller i sit virke forsøger at hele tendenser til moderne dualisme via sine ansatser til en sanselig kristendom. Gennem sportslig hærdning som en ny form for livsbesyngende 'askese' skal kroppen komme til ære og værdighed. Müller er et eksempel på, at mennesker omkring år 1900 kan trække spor fra en kristen opdragelse ind i opbygningen af det moderne samfund, hvilket kan give en vældig dynamik, men også medføre, at deres projekter løber løbsk pga. uerkendte religiøse understrømme. Eller mere konkret: Kan man, hvis man i 1870erne er vokset op i et dybt kristent miljø i en sådan grad, at man efter sin fars ønske studerer til præst, så blot ved et trylleslag i årtiet efter skifte over til den fremstormende hygiejnes medicinsk begrundede sundhedsoptimisme? I Müllers tilfælde er svaret nej.

Dennesidige længsler om at fuldkommengøre sig i den tidlige modernitet kan forstås i relation til Talcott Parsons og Niklas Luhmanns analyse af 'den dobbelte kristendom' (Gregersen 1988): det forhold, at der både eksisterer en officiel kristen kirke, men at der også kan foregå en 'diffusion' af kristent arvegods ud i nye former og i andre sektorer som musik og digtning - og altså også i gymnastik og hygiejne.

Relationer mellem krop og religion, sport og religion, og sundhed og religion er i dag specialfelter, som jeg af pladshensyn ikke kan gå i dybden med her. Dog skal inspiration fra forskningen i religion og askese fremhæves og herunder ikke mindst temanummeret herom i Religionsvidenskabeligt Tidsskrift fra 2016. I tilknytning hertil har Hans J. Lundager Jensens artikel fra 2013 “Udstigere og immunsystemer, asketer og akrobater", som det vil fremgå, været af særlig interesse (Sloterdijk 2011, 133-170).

Müllers kristent inspirerede forvandling af sit liv gennem systematisk sportstræning vil i det følgende blive fortolket i lyset af den tyske filosof Peter Sloterdijks tanker om, at en selvforvandlende praksis gennem øvelser er et genkommende tema i menneskets historie, der spænder fra religion og filosofi til musik og sport. Det tidligt moderne menneske kan derfor vanskeligt blot ændre sig via en viljesakt eller nye forestillinger, skønt sådanne selvfølgelig også hører med i en forandringsproces. Der skal træning til for at få de nye koder ind under huden.

I bogen Du musst dein Leben ändern fra 2009 viser Sloterdijk, at det nyskabende menneske er dømt til at øve sig gennem former for askese, et ord der i øvrigt kommer fra den antikke græske sports 'áskesis', der betyder 'øvelse', fra askeîn: 'at øve sig',

1 Jeg har gennem hele artiklen anvendt nutidig retskrivning. 
altså at træne (Sloterdijk 2011, 52-68). Det er i denne forstand, at Sloterdijk bruger ordet 'askese' som udtryk for års arbejde på selvformning, hvis mål er en bemestring, der fører til virtuositet - i reglen inden for en spirituel eller religiøs forklaringsramme. Også her rykker kroppen altså i centrum, for den antikke sports træning er simpelthen inspirationskilde til den vesterlandske søgen mod den selvtransformation, der videreføres i klosterlivet. Præcis den græske betydning af ordet passer som fod i hose på Müllers idrætspraksis, der søger mod fuldkommenhed gennem at dyrke legemet fremfor at fornægte det.

Et af Peter Sloterdijks hovedeksempler på at forvandle sig selv gennem træning er den franske baron Pierre de Coubertins etablering af de olympiske lege fra 1896 (ibid., 140-151). de Coubertin griber tilbage til den antikke verdens Zeus-dyrkende olympiske lege for at genskabe forbindelsen mellem religion og sport i den moderne verden: Gennem hård træning skal mennesket nå en stadig forbedring af sin ydeevne målt $\mathrm{i}$ centimeter, gram og sekunder. Man træner for at give sit liv en ny drejning og dermed træde i karakter som et subjekt eller ligefrem en stjerne på den olympiske himmel. Efterhånden står dog kun selve træningskonceptet samt de olympiske ritualer med edsaflæggelse, fredsduer og olympisk flag og hymne tilbage (Coubertin 1996, 122), mens de religiøse forestillinger for længst er visnet bort og mere og mere erstattet af politiske visioner.

Historikeren Ove Korsgaard har med inspiration fra den franske sociolog Émile Durkheim forsøgt at anskue det moderne samfund i et religionssociologisk perspektiv: Alle traditionelle samfund ses at bygge på en enhed af ritualer og myter, der forenes i kulten. Mange moderne mennesker kan ikke længere tro på de religiøse myter, men måske er der stadig behov for ritualer, der forankrer os i en kollektiv identitet? I så fald kan sporten ses som et sæt af ritualer, hvor vi med kroppen udtrykker fælles værdier. Med Korsgaards ord mangler den mytiske del af kulten, og vi dyrker altså nogle ritualer, uden at det umiddelbart kan sættes ind i en bredere fortolkningsramme (Korsgaard 1987, 223-242).

Men måske er der alligevel en fortolkningsramme, selvom den ikke er mytisk i klassisk forstand med guddomme, hellige genstande, skabelsesmyter, osv. Denne fortolkningsramme handler dybest set om dyrkelsen af fremskridtet målt i centimeter, gram og især sekunder. Det moderne samfund er et vækstsamfund målt med naturvidenskabelige målemetoder, og kernen i sporten handler om konstant at forbedre sin egen og fællesskabets sportslige præstationsevne. Det er her Müller viser sin moderne indstilling via sin rekordsprængende higen.

Når jeg i det følgende bruger udtrykket 'forvandling' og 'transformation' frem for '(selv)udvikling', er det for at markere en væsensforskel til de ofte overfladiske og ovenfra kommende krav om omstillingsparathed og forandringskultur, der er på mode i vor tid, og som ikke kræver grundig træning, men snarere bekendelser til evig fleksibilitet. ${ }^{2}$ For den trænende er transformationens mål ikke alene en bemestring af et givet felt, men også skabelse af en overføringsværdi, så træningen bliver en matrice, der borger for dedikation og ihærdighed på andre livsfelter.

2 Som Svend Brinkmann har kritiseret det i Stå fast! (Brinkmann 2014). 
Også i andre sammenhænge er sportens religiøse dimension blevet fremhævet. Gennem den såkaldte 'muscular Christianity' ('muskelkristendom') lærte de unge britiske mænd at blive gentlemen med mådehold og viljestyrke til brug for udviklingen af kapitalismen og ledelsen af det store imperium. På kostskolen Rugby blev ikke bare spillet af samme navn opfundet, men her blev også den nye 'sportsreligion' udviklet af rektoren Thomas Arnold Rugby, der ledte skolen fra 1828 til 1842. Hans budskab blev udbredt via Tom Hughes' roman Tom Browns Skoledage fra 1857. Også i Danmark - på Herlufsholm - var man med på bølgen med at bruge sporten i opdragelsen til gentlemen (Pedersen 2018, 311).

Müller er godt bekendt med Tom Browns Skoledage, som han benævner "denne udmærkede bog", og som han anbefaler sine læsere, idet han anfører, at den "findes i en meget billig udgave på dansk" (Müller 1900). Gennem muskelkristendommen har Müller fået et ideologisk grundlag, der forener en kristen tradition for askese med hans hærdende sportsdyrkelse som led i skabelsen af en ny etisk funderet mandetype.

Müller indgår i andre interessante religionshistoriske sammenhænge end det fremgår af artiklen. Her skal dog kun nævnes den indiske yogas udvikling i mellemkrigstiden, der synes af være inspireret af hans åndedrætsøvelser såvel som af - uden sammenhæng hermed - en anden verdenskendt dansk gymnastikpædagog, Niels Bukhs, smidiggørende gymnastik (Singleton 2010, 199ff).

\section{Müllers "system" til livsforandring}

Men hvem er denne Müller egentlig? Hans venner kalder ham bare Müller, fordi J'et $\mathrm{i}$ hans initialer udtales som ' $\mathrm{I}$ ' ligesom $\mathrm{fx}$ ved bryggeren J.C. Jacobsen, forfatteren J.P. Jacobsen. og politikeren J.C. Christensen. I de to sidste årtier af 1800-tallet udvikler Müller sig til Danmarks bedst kendte amatøridrætsmand, der sætter rekorder i et hav af nye idrætsgrene. Sammen med sine brødre på det såkaldte Müller-hold dominerer han i perioder dansk og skandinavisk kaproning.

Som vist i min bog fra 2020, Sundhedsapostlen J.P. Müller, ${ }^{3}$ kickstarter Müller i 1904 den første verdensomspændende motionsbølge med sin bog om hjemmegymnastik Mit System, der efterfølgende udgives på 26 sprog i halvanden million eksemplarer. Hverken Biblen eller H.C. Andersens eventyr kan i årene frem mod 1914 holde trit med de astronomiske salgstal. I den tyske kulturkreds bliver verbet 'zu müllern' optaget i sproget ${ }^{4}$ som udtryk for at dyrke hans gymnastik, der som daglig træning i en periode tages op af både traditionen i form af kejser Wilhelm og avantgarden i form af Franz Kafka.

Også i verdens førende land Storbritannien er der opbakning til Müllers budskaber både i det litterære og det royale establishment lige fra Conan Doyle til prinsen af Wales, den senere kong Edward VIII, der bliver protektor for Müllers bøger. Mit Sy-

\footnotetext{
3 Artiklen tager udgangspunkt i det i bogen fremlagte materiale og udvikler det i religionssociologisk retning.

4 Se fx http://www.duden.de/rechtschreibung/muellern.
} 
stem bliver simpelthen den mest succesfulde bog inden for fysisk kultur i Storbritannien i det tidlige 20. århundrede (Zweiniger-Bargielowska 2015, 248). Hele verden ligger for Müllers fødder, da han fra 1904 starter en turnérække med 1400 opvisninger, der omfatter mange europæiske lande og når helt til Sankt Petersborg.

Allerede for mere end hundrede år siden tager Müller livtag med de problemer, som i høj grad fylder i nutiden: fedmeepidemi, inaktivitet og dårlig ernæring. Müller tilbyder en enkel formel til at opnå det sunde, lange liv: nøgengymnastik med indbygget koldt bad og frottering af huden ved vinduer, der åbner op til den friske luft og mod solens lys (Müller 1904). Ved at skabe et basalt koncept for daglig fysisk træning med det formål at komme i form bliver Müller frontfigur i den tidlige udvikling af fitness.

Med Müllers system kan datidens mennesker bogstaveligt talt 'gnide' den kropsog seksualforskrækkede victorianisme. Gennem strygninger med håndfladen hen over huden efter badet påbegynder Müller et arbejde på at skabe en ny følsomhed over for den ret oversete og uberørte krop. Med Mit System bliver denne praksis til en verdensomspændende dille, hvor mennesker for alvor opdager deres hud med alle dens erogene zoner (Bonde 2020, 13-44).

\section{Fra protestantisme til vitalisme}

I 1884 kommer den unge falstring Jørgen Peter Müller til København. J.P. Müllers far er præst; broderen Paul og svogeren og vennen Fritz uddanner sig som præster; og selv drømmer Müller som ung om at blive salmedigter. Müller selv læser teologi på det meget bibeltro Teologiske Fakultet på Københavns Universitet, hvilket kaster ham ud i en dyb orienteringskrise. Der går således ikke lang tid før han har opgivet at basere sit liv på en teologisk karriere, for herefter deltager han uden større engagement i studierne, og al hans energi er rettet mod at dyrke sport og mod at opnå et job, der kan indbringe så meget, at han kan gifte sig med sin livsledsager Marie, hvilket først lykkes i 1893.

Samtidig med at Müller er begyndt at arbejde som varmeingeniør hos sin onkel Reck, lykkes det ham dog frem til 1894 at gennemføre de forberedende prøver med højeste karakter på teologi med studier i hebræisk og latin. Med hans egne ord lykkes det ham at tage 'både hebraicum og patristicum med laud'. Kort sagt er Müller blevet både sprog- og bibelkyndig i latinske skrifter og i hebraisk, hvilket skal komme ham til gode i hans senere brud med den herskende teologiske kønsmoral i bogen Kønsmoral og Livslykke fra 1908.

For den veltrænede, muskelsvulmende, solbrændte sportshelt Müller står der tydeligvis et valg mellem teologi og sundhed, når han sidder bænket ved pulten i beklumrede lokaler og med medynk kigger rundt på sine blege og spinkle studiekammerater. En ung medstuderende og lærernes favorit bliver for Müller en form for antihelt, der en dag i 1894 får bægeret til at flyde over for Müller:

En fyr, som sidder ved siden af mig med hele hovedet fuldt af filipenser, indgyder mig modbydelighed, og så er han oven i købet alle professorernes yndling, fordi han er søn 
af en berømt biskop. Denne mand som formentlig siden er blevet domprovst har en meget væsentlig andel i, at jeg en skønne dag knalder bøgerne i og forlader auditoriet, fast besluttet på at ofre resten af mit liv på at gøre den danske ungdom sundere (Bonde 2020, 127).

På KU er Müller i 1884 landet midt imellem tradition og modernitet, og især på universitetet opstår der en voldsom kulturkamp mellem religion og videnskab. Netop det år udkommer dagbladet Politiken for første gang, inspireret ikke mindst af Georg Brandes' moderne gennembrud, der markerer, at den kristne livstolkning i stigende grad kommer under pres. I denne brydningstid lander Müller i et opgør med sine egne lærere og professorer, som han mener misforvalter Kristi lære ved at fornægte menneskets sanselighed.

Müller opfatter det teologiske fakultet som støvet og dogmatisk, og faktisk er fakultetet meget konservativt. Fra højeste sted på universitetet tages der afstand fra den måde, teologien praktiseres på.

Matematikprofessor, Adolph Steen (1816-1886) provokerer i sin tale som rektor ved årsfesten i 1875 Det teologiske Fakultet "ved at hævde, at videnskabens metode er én, og at man ikke religiøst kan motivere kravet om 'naturstridige' resultater: teologien har kun hjemme på universitetet om den virkelig er fri forskning og ikke beror på 'noget udefra givet ... lige meget om (det) er et såkaldt religiøst liv eller en vis kreds af faste dogmer.'" (Mogens Müller 2013, 3).

Efter at J.P. Müller i protest har forladt teologistudiet, starter han på at udvikle sin egen kropsfilosofi både som idrætsudøver, som forfatter, som debattør og som sportsjournalist på Dansk Sports-Tidende og København (Bonde 2020, 145). Kort tid efter år 1900 sammenfatter han sit syn på udviklingen fra dyr til menneske med udgangspunkt i de seksuelle drifter:

Førhen troede menneskene i deres storhedsvanvid, at de var en slags åndelige væsener, $i$ et og alt ganske væsensforskellige fra dyrene. Kønsdriften var noget mennesket uvedkommende, ja fjendtligt, noget djævelen fik lov til at anvende til fristelse. Nu har menneskene erkendt, ikke at de er dyr, men at de står i slægtskabsforhold til dyreriget og som en følge deraf kan de nu indse at kød og kønsdrift hverken er noget djævelsk eller noget dyrisk, men simpelthen noget menneskeligt (Müller 1908, 274).

Müller vil intet mindre end at gøre op med 2000 års kristelig undertrykkelse af seksualiteten og forstyrrelse af "harmonien mellem legemets og åndens dyrkelse" (Müller 1908, 219).

I sin lære om kroppen kommer Müller især til at slå til lyd for to kerneprincipper: hærdning og renselse. Spørgsmålet er, om Müller virkelig har koblet sig fra den kristne grundskoling, eller om den befæstede og rene sportskrop i virkeligheden henter energi fra gamle kristne mentaliteter, hvor askese og mådehold fører til hærdning, og hvor renselse for synd bliver til renselse fra sved og skidt? Forsøger han at dyrke kroppen som et tempel, der forener det antikt græske princip om sportsøvelser ('áskesis') med en kristen karaktertræning?

Müller når frem til, at sporten ikke står i modsætning til den kristne moral. Tværtimod henviser han i et sportsblad fra 1892 med polemisk brod kristne kropsforagtere til den klassisk lutherske teolog, professor i etik og religionsfilosofi Henrik Scharlings 
kristelige sædelighedslære, hvor der i et afsnit om "Liv og Sundhed" står, at det er en "pligt at bevare, opretholde og uddanne det [legemet] til størst mulig sundhed og kraft." Der står også, at man bør have "den tilbørlige omsorg for legemets skønhed, som i de yngre år opnås ved gymnastisk uddannelse til smidighed og kraft." ${ }^{5}$

Müller ser i 1898 det at dyrke sit gudgivne legeme gennem udendørssport som en kristen handling. Han henviser til det gamle udtryk: 'Sygdom er hvermands herre'. Han finder, at dette 'misbrugte ord' sikkert ikke er udsprunget af nogen kristelig tanke, og dog anvendes det af en masse mennesker til at undskylde og dække over deres efterladenhed: "Jeg tror ikke, at Vor Herre anvender sygdom som straf for andre forsyndelser end netop den, at man ikke holder det i Guds billede skabte legeme i ære eller ringeagter den sol, den friske luft og den evne til bevægelse, som han har givet os" (Müller 1898a).

Ti år senere skærper han tonen, idet han skriver, at der snart vil komme en tid, da det vil blive anset for "en skam at være sygelig, fordi det skyldes synd og efterladenhed - altså noget umoralsk - hos vedkommende selv eller hos forældrene" (Müller 1908, 220). Syndsbegrebet flytter ind i sundhedslæren.

Gennem sin dyrkelse af den sunde, stærke krop i udendørs aktivitet knytter Müller an til den danske kunstneriske vitalisme, der udvikler sig efter århundredskiftet, og som priser det nøgne menneske, der boltrer sig i naturelementer som hav, sol og frisk luft (Hvidberg-Hansen 2008). Samtidig er Müller inspireret af den tyske tradition for 'livsreform', den tyske såkaldte livsreformbevægelses forsøg på allerede fra 1880'erne at skabe et nyt menneske via omfattende forandringer af hverdagslivet i retning af en mere 'naturlig' levevis (Wolbert 2001).

\section{Fra askese til hærdning}

Den danske teolog Niels Henrik Gregersen har med inspiration i Talcott Parsons og Niklas Luhmann argumenteret for eksistensen af en "dobbelt kristendom" (Gregersen 1988, 163-198); det forhold at der både eksisterer en officiel kirkelig kristendom og folkelige kristne understrømme, som manifesterer sig uden for kirkens rum (ibid., 839). I dette rum kan Müllers dyrkelse af hærdning og renselse ses som en videreudvikling af kristent arvegods i nye former.

Müller udvikler mere og mere en forestilling om, at man kan hærde sig gennem fysiske strabadser. De krævende idrætter udgør en styrkende kur, der vil sikre udøveren "et langt og lykkeligt liv" (Müller 1899). Kort sagt: jo mere man hærder sig, jo stærkere vil man blive, jo mere vil kroppen afvise sygdom, og jo længere vil man kunne leve.

Ved sin dyrkelse af udendørslivet i roning og atletik har Müller fået sans for lys, luft, vand og bevægelse. Gennem årene har han hærdet sig selv via en militærtjeneste, der fører ham til at blive sekondløjtnant i ingeniørtropperne, hvilket siden klæber til hans navn: Løjtnant J.P. Müller. Dertil kommer deltagelse i Akademisk Skyttekorps

5 Müller i Sport, 17. juni 1892. Se også Scharling 1896 [1885-86], 480. 
og den tidlige sportsbevægelses ekstreme forhold med elendigt løbeunderlag, manglende haller, udøvelse under alle slags vej- og vejrforhold, en dødsensfarlig skøjtetur i 1884 og en strabadserende løbetur fra Paris til Aachen i 1890 (Bonde 2020, 111-156). Müller har på egen krop mærket, hvor meget han kan tåle, og hvor meget kroppen kan udvikle sig. Heri ligger en hærdningsfilosofi i svøb.

Müllers ideer om hærdning er en reaktion på den såkaldte klunketids dyrkelse af indendørslivet ikke mindst faciliteret af varme omkring hjemmets arne. Mange af Müllers samtidige nyder, at de nu bl.a. takket være de moderne ovne kan undgå at fryse. Efter omkring 1840 havde hver større by mindst ét jernstøberi, der støbte ovne. Der var store salsovne, spisestueovne og små pigeværelsesovne. Man kunne købe ovne på hjul, som kunne flyttes fra stue til stue (Benzon 1980, 125). ${ }^{6}$

I stedet for at skutte sig omkring varmekilden langt fra naturens lunefuldheder, vil Müller omfavne naturelementerne. Hans pointe er, at den meget stillesidden og vægring ved udendørslivet faktisk gør mennesker udsatte, svagelige og kuldskære, hvorved de selv gør naturen fjendtlig og overmægtig. Men ifølge Müller er naturen faktisk god, og jo hårdere den tugter os, desto mere vokser vi.

Danmark har koldt sø- og havvand store dele af året, og Müller peger på det kolde vands sundhedsfremmende og opkvikkende kvaliteter. Og da landet har relativt lidt sol, peger Müller på, at solen også kan dyrkes vinter og efterår - endda nøgen. Det ubehagelige skal blive behageligt. Med baggrund i et Danmark med sne, regn og vind peger han på, at huden kun styrkes af at blive udsat for vind og vejr. Han kan ikke lave om på vejret, men kan måske skabe en ny mennesketype, der passer til vejret. Han søger ikke væk fra Danmark som store dele af overklassen, der starter en udenlandsk feriekultur i fx Harzen, men ind i Danmark med en krop der er i stand til at tilpasse sig omgivelserne.

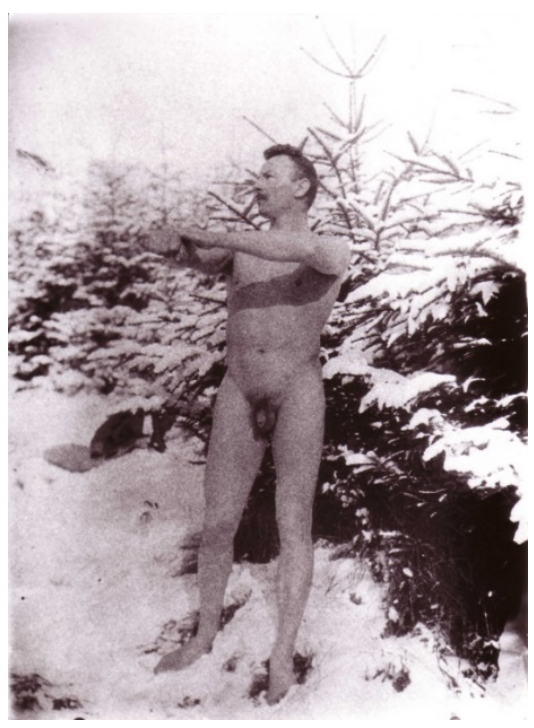

Müller hærder sig i bar vitalistisk figur i sneen i skoven ved Fakkegrav tæt på hans arbejdsplads Vejlefjord Sanatorium: Huden skal styrkes til at blive det robuste "beklædningsstykke" som det ny menneske skal profilere sig med. Ikke tøjet, men huden viser hvem du er. Dette foto var trods alt for vovet til at komme med i Mit System. Kilde: Privateje Hans Bonde 
På den ene side har Müller ret i, at forebyggelse mod sygdomme er vigtig for at bevare sundheden; på den anden side kan forebyggelsen blive så ekstrem, at den gøder jordbunden for sygdomme og derfor går over i sin modsætning. Svømning er sundt; men svømning i grødis, hvor nogle af iskrystallerne er frosset sammen, er ikke nødvendigvis sundt og i hvert fald ikke for alle mennesker. Sollys er godt; men hæmningsløs soldyrkelse er farlig. Men for Müller synes mere under alle omstændigheder at være bedre.

Med sin dyrkelse af hærdning skriver Müller sig ind i traditionen fra oplysningsfilosoffen John Locke, især dennes bog fra 1693 Tanker om opdragelsen, der fik betydning for det nye produktive borgerskabs opgør med de 'feminine', 'pyntesyge' og 'yndefulde' adelsmænd, der var mere orienteret mod luksus end mod et godt dagsværks arbejde.

For Locke er målet at skabe nye handlekraftige mænd, der gennem gode moralske egenskaber rækker ud mod samfundet. For at opnå det kræves der udvikling af en selvbeherskelse, der allerede starter med hærdning af børnene, ved at de får simpel kost, oplever udendørsliv med frisk luft og motion, herunder især svømning, at de ikke må græde, ikke klædes for varmt, og herunder at de vænnes til at have våde og kolde fødder (Locke 1996 [1693], 42ff.). Locke fremhæver den antikke bystat Sparta, for dette eksempel viser til fulde "hvor meget opdragelse kan vænne unge mennesker til smerte og lidelse" (ibid., 110).

Også den store inspirator af romantikkens tænkning, Jean-Jacques Rousseau, fremhæver i sin bog Emile (1762) hærdning, når børn og unge skal lære at stå på egne ben. I yderste konsekvens skal de kunne klare sig på 'islandske snemarker', for beskyttende omsorg svækker dem. Den ideelt opdragede dreng Emile skal også uddannes som snedker for at kunne bemestre håndens arbejde (Rousseau 1897,12. 260).

I Danmark udvikles der i slutningen af 1700-tallet en filantropisk gymnastik: en humanistisk-frigørende pædagogik, der bl.a. vil reformere latinskolen, og som er inspireret af Rousseaus tænkning om, at børnene skal ud i naturen og bruge kroppen. Således skriver gymnastikpædagogen Johann Christoph Friedrich GutsMuths (17591839) i anledning af sin gymnastikbog fra 1793 til kronprins Frederik [senere Kong Frederik VI, 1808-1839], at hans bog skal bekæmpe "enerverende forkælethed" og "luxuriøs blødagtighed." (Hansen 1998, 27).

Müller er faktisk direkte inspireret af Rousseaus hovedværk Emile og citerer ham for følgende fyndord: "Jo svagere legemet er, desto mere kommanderer det; jo kraftigere det er, desto bedre adlyder det" (Müller 1908, 271). Faktisk går Rousseau ikke ind for en helt fri børneopdragelse, men plæderer derimod for, at barnet via en kyndig vejleder selv udvikler sig og gør sig stærk - ikke mindst fysisk. Især oplevelsen af naturen kan virke hærdende: "Læg mærke til naturen og træd i dens fodspor. Den øver stadig børnene og hærder dem legemligt ved at prøve dem på forskellig måde; den begynder tidligt at lære dem, at der er noget, som smerter og gør ondt" (Roussean 1897, 19).

Uden at kende begrebet bliver Müller pioner inden for det, vi i dag kalder 'ekstremsport', fx når han i 1903 i Dansk Sundhedstidende hævder, at en kortvarig over- 
anstrengelse af en veltrænet sportsmand uden legemlige skavanker næppe er skadelig for helbredet. Müller har fx efter en kaproning været så anstrengt, at han har kastet galde op og ikke kan rejse sig selv op af båden. Et kvarter senere er han atter gået ud og har vundet et nyt løb, og skønt han igen passerer målet 'som halvdød', er han dog en halv time senere i stand til at ro og vinde for 3. gang.

I juni 1905 udkommer en række aviser med overskriften: "J. P Müller tør lade sig indpode tuberkulose." Müller rider åbenbart på en bølge af overmod efter sin lavineagtige succes med salget af Mit System, for han føler sig så sikker på at have hærdet sig optimalt, at han opfatter sig immun over for smittefare.

En medarbejder ved Nationaltidende har i juni 1905 haft en samtale med den nu "berømte J.P. Müller", der forklarer journalisten, at han har fået impulsen til at skrive Mit System gennem sit daglige ophold på Vejlefjord Sanatorium, fordi han ved stadig at færdes blandt de syge er blevet klar over "det ønskelige i at hærde menneskeheden mod sygdomme... ser De, lægerne plejer man at ty til, når det er galt fat. Først når sygdommen er eller synes et faktum, er doktoren i farvandet. Jeg ønsker at fortælle folk lidt om, hvorledes de på en praktisk og billig måde kan hærde sig mod sygdommens angreb." 7

I 1905 mener Müller gennem træning at have nået en sådan fuldkommenhed, at sygdomme simpelthen vil prelle af på hans ubesmittelige krop: "Jeg selv anser mig nu for at være af en sådan konstitution, at en mængde sygdomme vil stå ganske magtesløse over for min organisme. Jeg ville slet ikke tage i betænkning at lade mig tuberkulose indpode. Ja, det lyder dristigt, men det er min oprigtige overbevisning, at mine hvide blodlegemer nok skulle kunne holde selv et temmelig stort antal tuberkelbaciller stangen! Og De må erindre, at jeg endda ikke tør kalde mig helt sund. Jeg har i min barndom, både hjemme og i skolen, levet under samme uhygiejniske forhold som de fleste andre mennesker."

Det fremgår klart, at Müllers idé indgår i hans kampagne for at udbrede Mit System for en journalist: "Principielt mener De altså, at den, der fra sin første barndom opøves i at følge Deres 'system', vil være fuldkommen hærdet mod alle sygdomsangreb?" Hvortil Müller svarer: "Ja! Hans sunde organisme vil simpelthen afvise dem." 8 Mon Müller tænker på, hvad der kan ske, hvis nogle af hans tilhængere går i gang med lignende eksperimenter?

Müllers udtalelser om nærmest at skabe et usårligt overmenneske må have virket provokerende på mange og ikke mindst dem, der sørger over de mange af deres nærmeste, der er bukket under for sygdomme, der i dag kan kureres, men som dengang nærmest var en fast følgesvend i menneskelivet. Således kan pressen i juni 1906 meddele, at Müllers efterfølger som inspektør på Vejlefjord, den jævnaldrende PetersenSchepelern, er "afgået ved døden efter en operation for blindtarmsbetændelse, 39 år gammel." 9 På den anden side har netop drømmen om at kunne finde en kur mod sygdom og tidlig død kunnet drive mennesker i retning af Müllers forjættende sundhedsbudskab, hvor mange tidligere alene har måttet ty til bønner og gode handlinger.

Aarhus Stiftstidende, 16. juni 1905, s. 1. Artiklen stod oprindeligt i Nationaltidende.

Aarhus Stiftstidende, 16. juni 1905, s. 1. Artiklen stod oprindeligt i Nationaltidende.

Roskilde Dagblad, 7. juni 1906, s. 3. 
Gennem sit koncept om hærdning foregriber Müller i en ekstrem udgave den britiske forfatter Aldous Huxleys kritik i 1927 af det moderne princip om 'komfort', som videreføres af Karen Blixen nærmest som en maggiterning af hendes livssyn i hendes "Andet Daguerreotypi" (Blixen 1951, 64ff.). Huxley mener, at jagten på et behageligt liv uden uventede stød og knaster i den moderne tidsalder er blevet et formål i sig selv ("an end in itself"). Som modeksempel nævner han de feudale aristokrater, der efter hans opfattelse ofte sad på smukke, men radbrækkende møbler og i enorme, iskolde paladser, der var umulige at opvarme ordentligt. For dem var komfort ikke livets mål, men derimod at repræsentere sig mest korrekt, formfuldendt og værdigt (Huxley 1927, 283-299).

Sammenligningen mellem den kristne askese og sportsmandens træning kan virke søgt, men faktisk har denne sammenstilling oldkristne rødder. Selvfølgelig måtte apostlene grundlæggende tage afstand fra den antikke sport fx i Olympia, ikke mindst pga. dyrkelsen af hedenske guder, men apostlen Paulus så ikke desto mindre et slægtskab mellem idrætsmandens mådehold og stræben og den kristne afholdenhed, og han sammenligner deltagerne i Kristusmenigheden med atleter og sig selv med en løber og en bokser (Lundager Jensen 2013, 75-97):

Ved I ikke, at de, der er med i et løb på stadion, alle løber, men kun én får sejrsprisen? Løb sådan, at I vinder den! Men enhver idrætsmand er afholdende i alt - de andre for at få en sejrskrans, der visner, men vi for at få en, der ikke visner. Jeg løber derfor ikke hid og did, og jeg er ikke som en bokser, der slår i luften. Jeg er hård ved min krop og tvinger den til at lystre, for at jeg, der har prædiket for andre, ikke selv skal blive forkastet (1 Kor 9, 24-27).

Müllers tanker ligger tæt på citatet af Paulus, idet også han mener, at sporten kan give en sejrskrans, der ikke visner, fx i form af den størst mulige gudgivne sundhed og kraft, idet han som vist sammenknytter på den ene side den hårde sportstræning og på den anden side den engelske muskelkristendom og professor Scharlings sædelighedslære.

Skønt den katolske kirke op gennem middelalderen udviklede et had til kroppen som sæde for den frivole seksualitet, byggede kristendommen hos de gamle kirkefædre ikke på en forestilling om, at kroppen i sig selv skulle være syndig. Müller har altså fat i en lang ende, når han vil vriste kroppen ud af sin samtids teologiske syndsbevidsthed. Med teologerne Lisbet og Mogens Müllers ord er det græske ord for kødet, sarx, i Det Gamle Testamente "ikke blot en betegnelse for den døde kødmasse, men også for den levende organisme." Der bygges altså ikke på en "modsætning mellem det legemlige og det sjælelige, men kødet går på det hele menneske, og der ligger ikke noget foragteligt i ordet" (Müller \& Müller 2014, 263f.).

Ofte opfattes kristendommen som ekstremt kropsfornægtende. Men som bl.a. den franske historiker og filosof Michel Foucault har vist, er de tankestrømninger, der bekæmper krop og sanselighed, ofte de mest kropsfikserede (Foucault 1978, 26-45). Den kristne askese fokuserede også stærkt på, at man skal føle sin krop ikke gennem lyst, men gennem smerte og af og til gennem den lystfyldte smerte, der kunne føre til ekstase, som det fx ses i Berninis (1647-1652) statue af ‘Den Hellige Teresas ekstase' i den 
romerske kirke Santa Maria della Vittoria (Sturm 2015, 125ff.). Skønt målet er den sjælelige forening med guddommen, går vejen dertil gennem en fysisk trancetilstand.

\section{Fra askese til ekstase}

"Der åbnes altså herved en mulighed for at opnå lykken ubeskåret både her og hisset" (Müller 1908, 249).

Hvordan harmonerer Müllers religiøse bagage med hans sportsmani? Umiddelbart kan det virke som to modsætninger mellem en åndsdyrkende og en kropsdyrkende tradition, men dels var Müllers far positiv over for idræt, som han opmuntrede sine drenge til, dels er der faktisk noget $\mathrm{i}$ den hårde træning og sportens koder, som er foreneligt med kristne ideer. Munken og atleten er ikke så langt fra hinanden, som det kan synes, jf. begrebet askese/træning som forbinder de to. Ligesom munkene brugte forskellige ritualer til at transformere sig selv til at blive en ny slags mennesker, bruger sportsfolkene også træningen til at skabe sig selv om til nye individer med en særlig karakter.

For Müller har den sveddryppende sport endog kunnet forbindes med Det Gamle Testamentes ord: "I dit ansigts sved skal du spise dit brød, indtil du vender tilbage til jorden; thi af den er du taget" (1 Mos 3,19). Der kræves dog en forskydning, for i Biblen tales der om arbejde og ikke om sport. Det centrale begreb hærdning rummer hos Müller mulighed for smerte og forløsning på én og samme tid. Ligesom det kristne begreb passion indeholder en dobbelthed i form af både lidenskab og lidelse.

Umiddelbart kan det virke, som om Müller bevæger sig fra det indre til det ydre fra en pietistisk kristendom, hvor det drejer sig om en nøjsom levevis, der baner vej til Gud, til en dyrkelse af den atletiske krops skønhed og præstationer. Det passer også godt med, at der på det tidspunkt ikke er nogen præster blandt de danske sportsledere. Men skinnet bedrager. Det er næppe et tilfælde, at det er en præstesøn som Müller, der som en af de første virkelig tilegner sig og udbreder ideen om den hårde træning, der rummer ekkoer af en kristen askeses selvtvang.

Müllers gode ven, Berlingske-journalisten Asmus Diemer, der kender til og udbreder Müllers tanker, har vist, hvordan Müller forskyder sin interesse fra myten til ritualet, fra Biblens fortællinger til dens handlinger og fra den religiøse askese til sportens hærdning:

Müller er en præstesøn og har også selv været stud.theol. Men teologien var ham for tør og virkelighedsfjern. Han var nået til 'patristikken', hvor der læses kirkefædre som Ambrosius, Augustin og Thomas Aquinas. Men de gamle kirkefædre interesserede ham ikke rigtigt. Det vil sige, deres askese og bodsøvelser optog ham vældigt. Han betragtede nemlig disse under synsvinklen gymnastik- og hærdningsøvelser. Derimod brød han sig ikke en døjt om, hvad disse lærde og fromme mænd havde skrevet. Den måde at studere teologi på kan muligvis have sin tiltrækning, men til teologisk embedseksamen fører den ikke (Diemer 1913). 


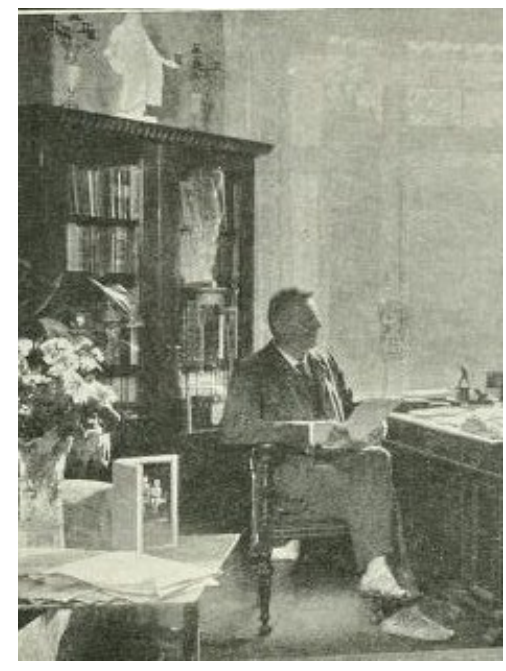

En miniature af Thorvaldsens vitale Kristus-figur i Vor Frue Kirke pryder fra 1905 Müllers dagligstue i Klampenborg. Her øverst på skabet bag Müller i hygiejniske sandaler. Statuens sårmærker i form af det lille snitsår under brystet kan Müller have tolket som et krav om gennem prøvelser og hærdninger at søge mod fuldkommenhed. Det er efter alt at dømme et par af Müllers sportslige sejrspokaler, der omkranser Kristus-figuren. Kilde: J.P. Müller: The Fresh Air Book. Health \& Strength, 1908, s. 1.

Kirkefædrene var strenge asketer, i øvrigt helt til forskel fra Jesus (Müller \& Müller 2014, 41). Skønt Müllers begreb om hærdning indeholder asketiske elementer, er han dog absolut imod, hvad han opfatter som den traditionelle kropsundertrykkende kristne askese, hvilket han i 1908 udtrykker præcist i en kritik af:

denne falske kristendom, der i snart 2000 år... har hævdet og næret en ensidig spiritualistisk livsanskuelse. Til at begynde hed det sig, at legemets syndige kød kun var et fornedrende, hæmmende hylster for den salige sjæl, hvorfor det var Gud velbehageligt, når man rigtig lod dette legeme forkrøbles i uhumskhed eller selvpinsler. Efterhånden som folk trods alt blev lidt fornuftigere, indskrænkede kirken sig til at kalde den personlige hygiejne enten verdslighed eller luksus eller farlig foregribelse af forsynets uransagelige vilje til at lede menneskeskæbnerne (Müller 1908, 277f.).

Ligesom Nietzsche afviser Müller denne kropsfornægtende askese, som man også ser i fx buddhistiske traditioner, hvor den religiøse udvikling indebærer en fuldstændig degenerering af kroppen. I stedet står både Müller og Nietzsche for livsbekræftende principper, i Nietzsches tilfælde i bogen Moralens Genealogi, hvor han kritiserer det, han kalder 'den kristne slavemoral' (Nietzsche 1887, 270f.).

Müller starter det sidste afsnit i sin bog Kønsmoral og Livslykke fra 1908 med at citere Nietzsche: "Den tid vil komme, hvor vi skal betale for i to årtusinder at have været kristne". ${ }^{10}$ Müller fortsætter: "Meget tyder på, at denne tid allerede er kommet, ikke alene for Tyskland, men fx også for Danmark. Men lad mig for at undgå misforståelser straks gøre opmærksom på, at den kristendom, som Nietzsche her angriber, er den samme som den, vor egen Søren Kierkegaard trevlede op, nemlig den verdslige, embedsmæssige, officielle, overfladiske dogme-kristendom, hvis støtter altid og hvis tjenere som oftest er ligeså angst for Kristi sande lære om selvfornægtelse, fordragelighed og menneskekærlighed, som djævelen for det hellige kors" (Müller 1908, 277).

Müller citerer herefter Nietzsche: "Bort med al medlidenhed, barmhjertighed og velgørenhed. Den sande kærlighed er hård. Den lader de svage og ynkelige dø til fordel for de sunde og stærke." Müller tilføjer: "Men ville det ikke være mere humant, 
mere moralsk, at skåne disse stakler for deres pinsler og nød ved slet ikke at give dem livet?" (ibid.) Herved kobler Müller sig på samtidens stærke dyrkelse af eugenik, en racehygiejne der skal forbedre menneskeslægten gennem begrænsning af de 'dårligst egnedes' ret til at få børn.

Müllers princip om hærdning bliver en form for lystfuld asketisk praksis, hvor man ganske vist disciplinerer sig til ikke at følge sine umiddelbare lyster for at i stedet at træne sit legeme. Men denne træning kan give en sanselig tilfredsstillelse og oven i købet en god samvittighed, fordi man har undladt at synde mod kravet om at gøre sit legeme sundt. Med hærdningen forbinder Müller den traditionelle kristne askeses stræben mod ophøjede mål med den nye moderne sports koncept om træning.

Müller er ikke en mand, der skåner sig selv. Det bliver tydeligt, da han i oktober 1890 sætter sig for at sætte en landevejs-rekord i 'Gå som du vil-løb' ("Go as you please") på strækningen Paris - Hamborg, hvor han helst vil nå op på 100 kilometer i døgnet. Inden turen har han trænet otte dage i omegnen af Paris.

Müller har jo forladt teologistudiet i protest; men han kan tydeligvis finde afløb for religiøse længsler i løbet, som bringer ham på kanten mellem kollaps og ekstase. Han beskriver i et sportsblad en nærmest bibelsk vej mod den endelige forløsning på med hans egne ord 'apostlenes heste', altså til fods. Fra starten plages han af utallige uheld og strabadser, der kan give hans læsere mindelser om Det Gamle Testamentes beretning om Ægyptens ti plager. Lige fra starten må 'forsynet pludselig have indset, at Frankrig trænger hårdt til at vandes, thi på den dag åbnes himlens sluser, og i 4 døgn regner det næsten uafbrudt'. Derpå følger utallige prøvelser som gang og løb på farlige veje også om natten med fare for kriminelle overfald, opløste veje, beskidte gader i tæt kulstøv fra de mange huse, tab af orientering, perioder med sult og tørst og hudløshed på anklen med voksende smerter - og som kulmination tab af hans pengepung (Müller 1890).

Den sidste dag kl. halv seks om morgen kan Müller næsten ikke mere. Tåge og gennemtrængende kulde isner hans krop. Kun under fodsålerne brænder det med en fornemmelse af 'tusind knappenålsstik' Han støtter sig tungt til paraplyen og slæber benene efter sig, mens søvnen er lige ved at overmande ham. Det hele minder om Jørgen Leths udlægning af cykelløbets strabadser også i det franske i filmklassikeren En forårsdag $i$ Helvede fra 1976 om det klassiske cykelløb Paris-Roubaix.

Men så sker forvandlingen: Der sker 'ligefrem et mirakel' med Müller. Uden nogen ydre årsag bliver han i mindre end fem minutter så let og livlig, at han løber to kilometer og fortsætter dernæst marchen med en fart af en mil i timen. Søvnighed, udmattelse og ømhed er som blæst bort, og hans forbavselse og glæde kender ingen grænser til trods for, at han må opgive sin videre færd, da han er nået frem til Aachen. Den mystiske oplevelse er ikke ny for ham, for han har før iagttaget en "sådan tilsyneladende umotiveret fornyelse af livskraften, men aldrig så påfaldende tydelig" (Müller 1890).

Müllers opsøgning af sådanne nærmest mystiske oplevelser ligger godt i forlængelse af Nietzsches idé i værket Tragediens Fødsel fra 1872 om at 'opsøge livskraften', at 'gå til livets kilde', at 'elske det meningsløse', og at leve intenst. Nietzsches dyrkelse af det intense nærvær rummer ikke bare fryd, men også lidelsen: 'Livet er strid, ikke 
harmonisering'. Ja, gru og glæde betinger hinanden. I ekstasen, hvor 'individet opgår i altet, oplever mennesket en lykke fuld af kval' (Jørgensen 2010, 177-201. Jf. også Dam 2010, 54). Eller med Johannes V. Jensens ord er der tale om "mytiske øjeblikke, hvor en større livsenhed sammenskues" (Dam 2010, 49).

Müller søger mod en dybtgående transformation, der nærmest hviler på en åbenbaring af livets sande mening. Han bruger typisk religiøse metaforer, når han skal beskrive de grænseoverskridende tilstande i fx roning, der gør, at han må se med overbærenhed på dem, der stadig træller i det almindelige liv: "Den, der ikke har oplevet det, aner ikke, hvad det er for en guddommelig fornemmelse at ro langs kysten i den friske søluft, mens man inde på land langs hele strandvejen ser vogne og cyklister ase afsted i tætte grå støvskyer." 11

\section{Renselse}

"Mennesket er en luft- og lysskabning" (Müller, 1906, 31).

Den gryende sportsbevægelse med Müller som bannerfører opfatter sveden som et tegn på en vital forandring, der udskiller farlige stoffer, som har ophobet sig på huden. I 1898 skriver han: "Med sveden forlader også alle usunde stoffer og mulige sygdomskim legemet på naturlig måde, ligesom man bliver af med overflødigt og usundt fedt. Mange tror, at det er en svag mand, der hurtigt kommer i sved. Nej, det er netop tegn på en sund og virksom hud og bevis på en god hudpleje" (Müller 1898).

At svede bliver i sig selv en form for eksistentiel renselse, hvor kroppen skiller sig af med det urene, ja det ligefrem livstruende giftige. Hermed er Müller på vej mod sin teori om, at manglende renlighed resulterer i en form for selvforgiftning. Den kommer til udfoldelse i fuldt flor med Mit System: Efter de svedfremkaldende øvelser kommer et bad i et lille fladt kar med gerne koldt vand, der igen følges af gnidninger af hele kroppen, først med et håndklæde og herefter med håndfladerne.

For Müller er kampen for den rene hud en livsvigtig sag. Den rene, sunde mand vil ifølge Müller udvikle en modstandskraft over for de nye trusler mod menneskekroppen. I 1898 skriver Müller: "Det er ikke længere vilde dyr, krig og dueller, manden skal værne sig mod": "Nu om stunder går det ikke an at spidde en uven på kården, og de allerfarligste dødsfjender, bacillerne, der lurer i hver en krog, de kan ikke rammes af et skarphvæsset spyd eller kvæles med et stranguler-greb (Müller 1898b.)"

11 J.P. Müller: "Læg Dem efter Roning" København, 13. maj 1897. 
Som højdepunkt i sin interesse for renlighed vælger Müller som forsidebillede til Mit System den græske statue Apoxyomenos af Lysippos. Müller skriver, at det er med velberåd hu, at han blandt de mange dejlige klassiske statuer netop har valgt Apoxyomenos til at pryde sin bog: "Thi han er en legemliggørelse af bogens indhold: Det er idrætsmanden, der efter øvelser renser og plejer sin hud, og det er tillige det ideal, til hvilket min bog viser frem. Under dette mærke, i reglen forkortet til Apox eller Ap, skrev jeg i en årrække om idræt" (Müller 1904, kolofonen). Müller er over-

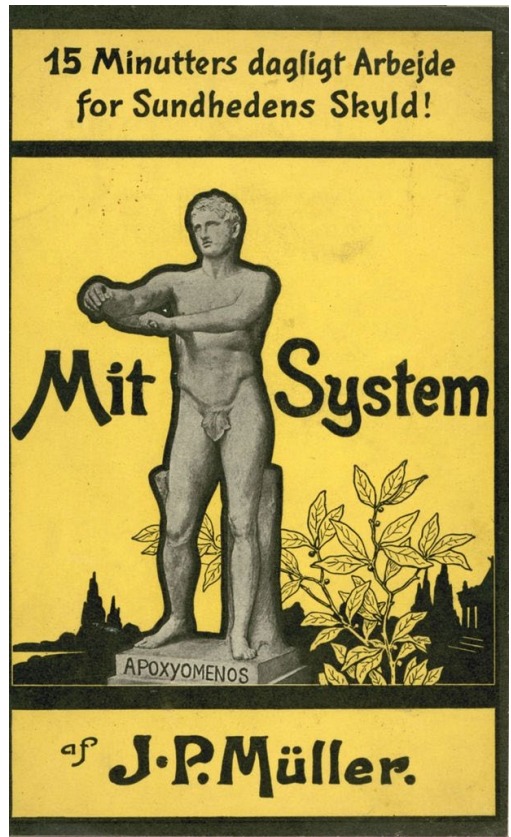

Müllers brug af "Skraberen" til forsiden af sin bog. Müller søger slavisk at følge de antikke græske sportsstatuers normer bortset fra ét punkt, overskægget, der bliver hans signatur. Kilde: J. P. Müller: Mit System. Tillges Boghandel, 1904.

bevist om, at han har frembragt en krop, der vil afvise ethvert sygdomsangreb, og på den baggrund fremstår han som lutret og renset. Med en følelse af absolut sikkerhed om sin mission påbegynder Müller i sin journalistik og i sit hverdagsliv en kamp mod sine medmenneskers vaner for at få åbnet vinduer i "stuer, sovekamre, i selskaber, på caféer, i teatre og forsamlingssale, i sporvogne og jernbanekupéer" (Müller 1903), ja overalt, hvor der er indelukket.

Lægen Frode S. Sadolin - en af Müllers våbenbrødre i kampen for idræt og hygiejne - har en bror, Jørgen T. Sadolin, der er sognepræst. Han fornemmer klart et religiøst aspekt i udbredelsen af sportens renlighedsprojekt. I en artikel med titlen "Badets betydning for sjælelig renhed" skriver han i 1906 i et gymnastikblad, at han ofte har tænkt på de renselsesskikke, som Moseloven foreskrev ${ }^{12}$. Han tvivler ikke om, at "de i betydelig grad har tjent til at fremelske sindets renhed, særlig hvad kønslivet angår. Og den samme betydning kan badet få den dag i dag..." (Sadolin 1906, 65f).

Der er oprindeligt en tanke, der findes hos Luther, at synd gør en sårbar over for angreb fra sygdomsfremkaldende djævle (Schilling 2014). Hos Müller bliver man sårbar over for angreb fra bakterier, hvis man synder ved ikke at pleje sin gudgivne krop.

12 Se fx 3 Mos 8,20, hvor der er love om renselsesriter, når en sygdomsramt erklæres ren; jf. Müller \& Müller 2014, 371. 
Hverken smådjævle eller bakterier kan man se; men man ved, at de er der, og således har fjenden fået nyt navn, men den samme angst for at blive ramt af sygdom og død består. Og Müllers pointe er: Hvis vi lever et liv renset for urenheder, vil vi bedre kunne værne os mod farerne.

Som det fremgår, har den nye bakteriologi en stærk billeddannende kraft, som Müller forstår at udtrykke til fulde. Forestillingen om, at vi er "belejrede af små usynlige dyr, der kribler og krabler, og kan overføres fra menneske til menneske og fra urene til rene ting, er ikke alene let forståelig; den giver også et fysisk ubehag ved de situationer, hvor denne overføring kan ske. Mikroberne er en angribende fjende, som lægevidenskaben udkæmper en forsvarskrig imod." Müller kan her være inspireret af den "første populære fremstilling af bakteriologien på dansk fra 1884 med den sigende titel: Vore usynlige fjender" (Jacobsen \& Larsen 2007, 152; jf. Poulsen 1884).

I det hele taget bliver bakteriologien på det tidspunkt den vigtigste videnskabelige disciplin, fordi:"Med et slag fik det, som før havde været et naturens lune, Guds eller den blinde skæbnes vilje, en fysisk håndgribelig forklaring, som alle kunne forstå. Bakterierne havde været kendt længe, men nu fik de navne og kunne sammenkædes med de konkrete sygdomme, som de forårsagede" (Jacobsen \& Larsen 2007, 152).

Müllers forestillinger om renselse fører ham over i visioner om en nærmest dennesidig frelse, om det hygiejniske menneskes almagt, en nærmest fuldstændig kontrol over egen sundhed og livslængde, der for de opvoksende generationer kan nærme sig de halvandet hundrede år: "I skole- og læretiden er vi alle ligefrem blevet tvunget til at indånde gift. Deraf følger, at intet nulevende menneske kan gøre sig håb om at nå de 140 år". ${ }^{13}$ Men omvendt mener Müller, at et menneske, der lever fuldstændig hygiejnisk, vil kunne blive mindst 150 år gammel.

Hvor man i middelalderen betonede "Memento mori": "Husk at du skal dø", bliver døden hos Müller i Mit System udskudt på ubestemt tid eller i hvert fald til de 140, hvis man vel at mærke lever hygiejnisk. Hvor Müllers far prædikede frelse som noget der først fuldbyrdes i himmerige, skimter Müller himmerige på jord i kraft af et ufatteligt langt liv befriet fra sårbarhed, udsathed og sygdom.

Med en kristen sprogbrug om synd hævder han, at de forskellige "forsyndelser mod hygiejnen" forkorter levealderen. Den almindeligste 'synd', som "uden undtagelse alle gør eller har gjort sig skyldig i, er indåndingen af fordærvet luft. Her har vi efter al sandsynlighed hovedårsagen til den korte levealder." Død og fordærv venter den, der synder mod hygiejnens krav: "Alle væv og organer bliver lidt efter lidt gennemsyrede af gifte og taber derved deres modstandskraft og levedygtighed. Selv om folk spadserer et par timer daglig i fri luft, indånder de dog gift hele den øvrige tid" i alle de indelukkede rum (Müller 1898).

Den danske historiker Troels Troels-Lund ser samme år paralleller mellem renæssancens religiøse frygt for små-djævle og det tidligt moderne menneskes frygt for bakterier. Han viser, at "det Onde" i det 16. århundrede manifesterede sig i opfattelsen af "alting opfyldt af billioner og atter billioner ondsindede djævle". Skønt TroelsLunds og Müllers samtid må afvise denne forklaring, har ifølge Troels-Lund "netop

13 Müller i Idrætten, 31. januar 1906. 
vor tid givet ganske det samme svar på det tilsvarende nutidsspørgsmål. Sygdom er i vore dage blevet forklaret som virkning af visse bakterier og baciller, der i uendeligt tal fylder luften og vort eget legeme, smittebringende, rede til fordærv."

Med inspiration i den moderne lægevidenskab forudsættes det, at "et tilsvarende antal sundhedstropper, fx de hvide blodlegemer eller lignende, vel nok holder sygdomsdjævlene stangen. Vi overlader med andre ord til en højere magt, naturen, at klare den sag, vi i de allerfleste tilfælde er ganske ude af stand til at magte" (TroelsLund 1898, 138). Eller med historikeren Bente Rosenbecks ord: "Kampen mod det onde blev erstattet af kampen mod bakterier" (Rosenbeck 1992, 33).

Ligesom hos middelaldermunken er angsten for mørkets magt og kampen for renheden solidt plantet i Müller. Men modsat munken, der gemmer kroppen bag en mørk kutte, vil Müller af med alt tøjet og have kroppen ud i det fri, hvor den kan blive helet og renset og skinne. Hvor munken ser hæmningsløs latter som gudsbespottende, ser Müller latteren som godt for et frit åndedræt (Müller 1914, 31). Müller pisker ikke sig selv som flagellanten, men pisker sig fremad i al slags vejr.

For Müller kan sportens udendørsliv ligefrem føre væk fra alt fordærv og ligefrem føre til en momentan genfødsel, for "man er et nyt menneske, når man om morgenen eller aftenen har taget sit styrtebad efter en kort, rask ro-tur på det friske vand". ${ }^{14}$

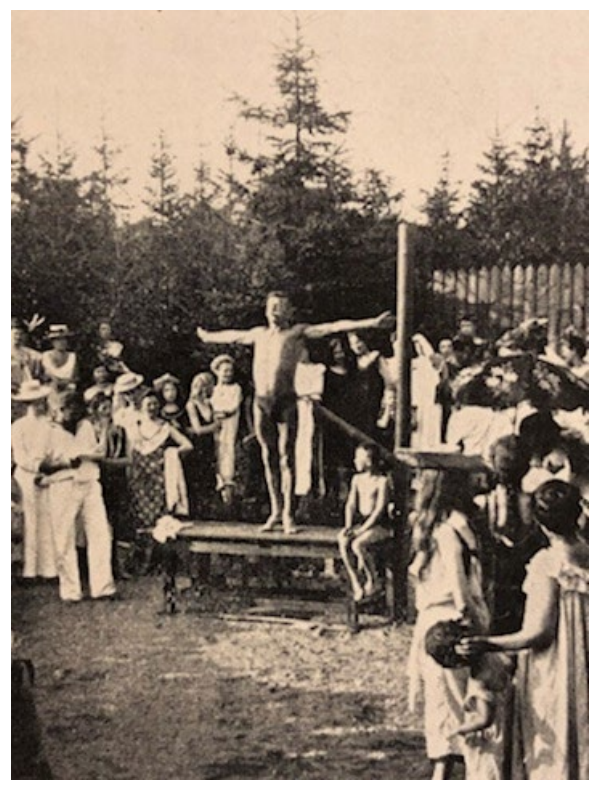

Fra en opvisning for kvindelige badegæster i Waidberg i Tyskland i 1906. Gennem træning, der forbinder til elementerne, til forløsning. Solens stråler og den friske luft, der gennemtrænger kroppen, medfører en dybtgående rensning. Müller indtager her via en åndedrætsøvelse den såkaldte adorant-positur, hvor lyset og solen nærmest tilbedes med udstrakte arme. En sådan positur findes i religionshistorien helt tilbage til Farao Akhnaton og hans families dyrkelse af solguden Aton. ${ }^{1}$ Om den kristne kirke heri har været inspireret af den korsfæstede positur er mig ubekendt. Kilde: J.P. Müller: The Fresh-Air Book. Health \& Strength, 1908, s. 36a.

I den kristne tradition er det at rense sig for syndige tanker et centralt element, og renselsen kan dermed være udtryk for en kontinuitet i Müllers liv, der pendler mellem kristendom og sport. Den, der renser sig, bevæger sig fra en sfære til en anden, fra urent til rent, og træder ind i en anden verden ved helt at lade sig omslutte af 
vandet som symbol på det rene, gennemsigtige element - jf. vandets betydning gennem dåben som kristent sakramente.

I Det Gamle Testamente ses sygdom ofte som et resultat af menneskets syndighed (fx 2 Krøn 21,5-20). I Det Nye Testamente er det Satan og hans dæmoner, der gør mennesker syge, mens Jesus omvendt helbreder de syge (fx Luk 10,18). Her står Gud som den, der helbreder gennem Jesus (fx Mark 8,31-37). Målet er frelse og en forsmag på Guds Rige (fx Matt 12,28), ikke sundhed som et gode i sig selv som hos Müller. Ikke desto mindre kan Müllers sundhedslære ses i forlængelse af den kristne tradition, både når han taler om, at mennesket synder mod sin natur og derfor rammes af sygdom, og når han hævder, at mennesket kan forebygge og helbrede gennem at leve i overensstemmelse med naturens love. Naturen indtager Guds plads; men i inspirationen fra muskelkristendommen glider de to begreber over i hinanden.

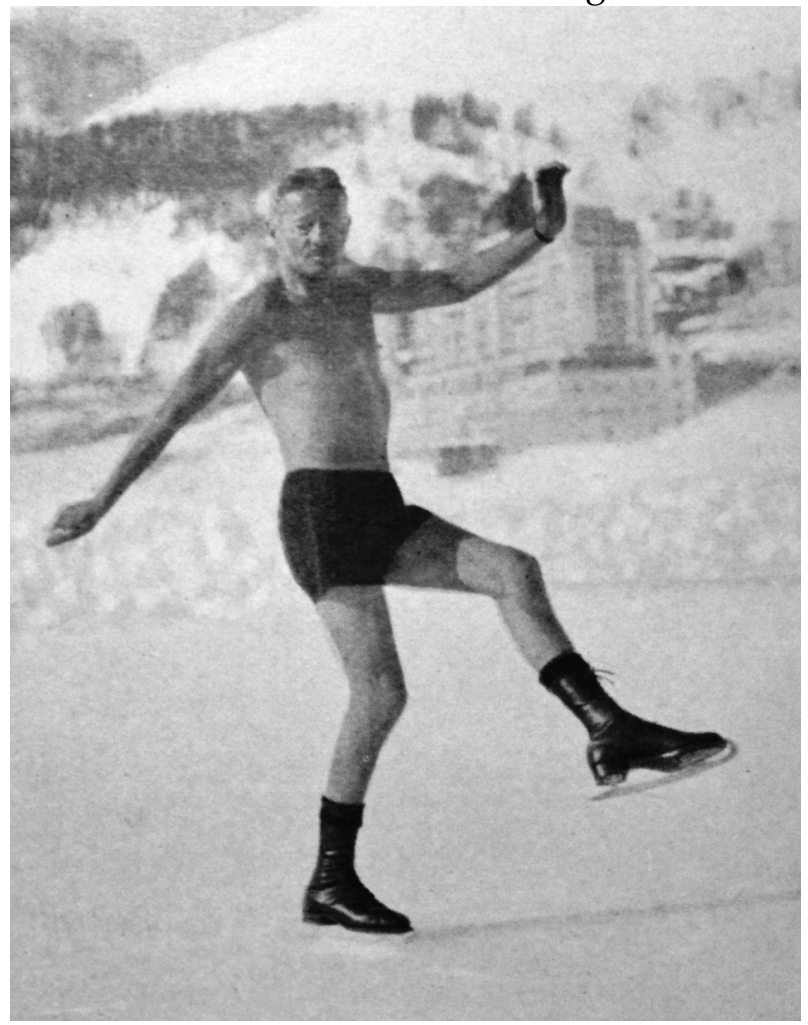

Müller demonstrerer som lidt ældre herre skøjteløb i St. Moritz i Schweiz, hvor han sammen med sin familie slår sig ned i 1911-12 som byens æresgæst med egen fri bolig. Kilde: J.P. Müller: My Sunbathing and Fresh-Air System. Athletic Publications, Ltd., 1927, s. 36.

\section{Vækkelse gennem kroppen}

Alt i alt bygger Müller ikke en institutionalisereret kirke; men for ham skal kroppen blive et tempel, der åbner mod det guddommelige. Müller forkaster statskirkens kristendomsopfattelse og medvirker til at skabe en fordobling af den kristelige virkningshistorie ved at lade kristne ideer vandre over i udendørssport, gymnastik og hygiejne. For at nå dertil må Müller bruge hele sin ungdomstid på at vriste sig fri af kristne vaneforestillinger og finde et nyt ståsted, der ikke forkaster Kristi lære, men fortolker den i et helt nyt lys i pagt med tidens gryende sansevækkelse. 
Müllers koncept 'hærdning' står således både i gæld til den antikke græske sports øvelser og til de kristne kirkefædres selvtugt, der i begge tilfælde betegnes med det græske ord for træning, 'áskesis', men med væsensforskelligt mål. Ved at træne nøgen i naturen kan der ifølge Müller foregå en ydre og indre renselse via kontakt med vand, vind og sol, der påvirker både hudens og de indre organers stofskifte. Gennem dybe åndedrag i den friske luft iltes blodet, og giftstoffer udskilles, så Müller og hans følgere kan fremstå lutrede og rene.

Der er en dyb enhed mellem Müllers to grundbegreber renselse og hærdning. Renselsen hærder. Og hærdelsen renser. At trække vejret i ren luft, at lade solen afbrænde bakterierne på huden, at lade vandet skylle kroppen ren og at bevæge sig kraftfuldt, så stofskiftet kan rense de indre organer har alt sammen til formål at hærde kroppen.

Hos Müller vandrer de kristne forestillinger om 'renhed' og 'evigt liv' over i hans hygiejniske system. Centralt i Müllers gymnastikprogram står de gymnastiske øvelser, der skal udføres i soveværelset for åbent vindue i frisk luft. Müllers forestillinger om renselse fører ham over i visioner om en nærmest dennesidig frelse, om det hygiejniske menneskes almagt, en nærmest fuldstændig kontrol over egen sundhed og livslængde, der for de opvoksende generationer kan nærme sig de 150 år.

Hvor Müllers far prædikede frelse som noget, der først fuldbyrdes i Himmerige, skimter Müller et himmerige på jord i kraft af et ufatteligt langt liv befriet fra sårbarhed, udsathed og sygdom. Med en kristen sprogbrug om synd hævder Müller, at de forskellige 'forsyndelser mod hygiejnen' forkorter levealderen. Den almindeligste 'synd, som uden undtagelse alle gør eller har gjort sig skyldig i, er indåndingen af fordærvet luft.

Müllers nøgleord 'hærdning' og 'renselse' indgår også som kernebegreber i den tyske filosof Peter Sloterdijks definition på religiøse, filosofiske og spirituelle systemers transformative kraft, men her i form af ordene 'immunisering' og 'væmmeliggørelse' ('Verekelung'). Sloterdijk opløser den traditionelle modsætning mellem religiøse og verdslige systemer, idet han træder et skridt tilbage, hvorved han kan se lighedstræk mellem alle systemer, der bygger på træning til selvforvandling, hvoraf de religiøse kun udgør én - men til gengæld en central form.

Med 'immunologi' mener Sloterdijk, at sociale systemer for at overleve og videreudvikle sig er nødt til at skabe kulturel modstandsdygtighed. ${ }^{15}$ Det harmonerer med Müllers 'hærdning', som helt bogstaveligt sigter på at styrke immunforsvaret i en sådan grad, at mennesket bliver overmenneske, både hvad angår sundhed og levealder.

Det andet nøglebegreb hos Sloterdijk er 'væmmeliggørelse', som signalerer, at det selvforvandlende menneske i udgangspunktet bør lære at se den umiddelbart givne verden som ækel og gennem øvelser forsøger at løfte sig mod en ny, ophøjet virkelighed, ${ }^{16}$ - som søjlehelgenen, der bogstaveligt forsøger at løfte sig ud af verden til en ny virkelighed.

Sloterdijk 2011, 19-24; jf. Lundager Jensen 2013, 78ff; $86 f$.

16 Sloterdijk 2011, 364-366; jf. Lundager Jensen 2013, 86f. 
Så radikal er Müller ikke, for han står med fødderne solidt plantet i verden; men han gennemfører ikke desto mindre med endnu et af Sloterdijks nøgleord en 'udstigning' ${ }^{17}$ af samfundet for at træne sig til et nyt livskoncept i det fri, og han ser med medlidenhed på alle de almindelige jordbundne mennesker i støvskyer på vejene, når han glider forbi ude på vandet i sin robåd. Han erklærer også krig mod alle de urene aspekter af verden, som stikker i næsen, og som i form af baciller truer fra hvert et hjørne. Kun gennem udrensning af de kvælende og livstruende giftstoffer kan en ny sund virkelighed skabes og mennesket nå sin egentlige bestemmelse.

Sammenligningen mellem protestantisme og sport skal ikke overdrives. Det nye og banebrydende ved sporten i forhold til den protestantiske præstationsbevidsthed og arbejdsmoral er sportens fysisk aktive og livslystne aspekt. Sporten i Müllers aftapning består ikke kun af former for faste, mådehold og renselse, men i høj grad af et bevægelsesmæssigt tilvalg. Kroppen skal gøre noget fysisk aktivt for at kunne rense og hærde sig.

At Müllers tilslutning til den britiske muskelkristendom, til teologen Henrik Scharlings kristelige sædelighedslære og hans udvikling af sine egne forestillinger om renselse og hærdning ikke er en enlig religiøs svale i hans kropsligt-religiøse udvikling, ses af, at han nogle år senere - i 1908 - fremlægger intet mindre end et forsøg på en ny legering af erotik og kristendom (Bonde 2020, 212-221) og fra 1930 udvikler en healing og spiritisme, der fører ham ind i en åndeverden, hvor han møder et helt englehierarki og i sidste ende selveste Jesus (Bonde 2020, 370). Müller kan altså ses som et tidligt varsel om hele den spirituelle alternative kropskultur, der er vokset frem gennem de seneste generationer.

For en præstesøn som Müller kan den kristne nøjsomhed altså forvandles til en sportslig hærdning, hvilket kan sikre, at et menneske på kanten mellem det traditionelle og det moderne kan undgå en form for mental splittelse og optage det gamle i nye former. Traditionen bliver et vigtigt afsæt for skabelsen af det nye, og Müller kan føle sig i pagt med meget af sin barndoms kristne lærdom om at disciplinere sit legeme, samtidig med at han giver denne disciplinering en helt ny sanselig og lystfuld mening.

\section{LITTERATUR}

Benzon, Gorm

1980 Gamle ovne i Danmark, Kreditforeningen Danmark.

Blixen, Karen

1951 Daguerreotypier, Gyldendal.

Bonde, Hans

2013 "Projection of male fantasies: The creation of 'scientific' female gymnastics", in: Gigliola Gori \& J. A. Mangan, eds., Sport and the Emancipation of European Women: The Struggle for Self-Fulfilment, Routledge.

17 Sloterdijk 2011, 338-355 
2020 Sundhedsapostlen J.P. Müller, Syddansk Universitetsforlag.

Brinkmann, Svend

2014 Stå fast!, Gyldendal.

Coubertin, Pierre de

1996 Den olympiske idé, Det lille Forlag.

Dam, Anders Ehlers

2010 Den vitalistiske strømning - $i$ dansk litteratur omkring år 1900, Aarhus Universitetsforlag.

Diemer, Asmus

1913 “The Muller Institute", Verden og Vi, 26. december 1913. https://doi.org/10.25291/VR/1913-VLR26

Foucault, Michel

1978 Seksualitetens historie, bind 1, Rhodos.

Gregersen, Niels Henrik

1988a “Den dobbelte kristendom", Præsteforeningens Blad 40, 835-847.

1988b Teologi og kultur. Protestantismen mellem isolation og assimilation i det 19. og 20. Arhundrede, Aarhus Universitetsforlag.

Hansen, Jørn

1998 "Politics and gymnastics in a frontier area", The Nordic World: Sport in Society, 25-46. https://doi.org/10.1080/09523369708713999

Huxley, Aldous

1927 Proper Studies, Chatto \& Windus.

Hvidberg-Hansen, Gertrud \& Oelsner, Gertrud, eds.

2008 Livslyst-Sundhed - Skønhed - Styrke i dansk kunst 1890-1940, Museum Tusculanum Press.

Jacobsen, Kurt \& Larsen, Klaus

2007 Ve og velfærd. Læger, sundhed og samfund gennem 200 år, Lindhardt og Ringhof.

Jørgensen, A. A.

2010 "Vitalisme på dansk - en præsentation", Tijdschrift voor Skandinavistiek, vol. 31, 177-201.

Korsgaard, Ove

1987 "Fra ritual til ritual", Centring 2, 223-242.

Locke, John

1996 [1693] Some thoughts concerning Education, Hackett Publishing Co.

Lundager Jensen, Hans J.

2013 “Udstigere og immunsystemer, asketer og akrobater", Religionsvidenskabeligt Tidsskrift 60, 75-97. https://doi.org/10.7146/rt.v0i60.20411

Müller, J.P.

1890 "En Fodtour fra Paris til Aachen", Dansk Sportstidende.

1898a "Hvorfor bør man løbe?" Søndagsbladet, 20. februar og 6. marts 1898.

1898b "Vore saakaldte athletklubber - triste erfaringer", København, 30. januar 1898.

1899 "Lidt om Athletik-Sport", Isefjords-Posten, 26. november 1899.

1900 “Om Terrænløb", Dansk Idrætsblad, 16. marts 1900.

1903 “Hvordan skal man leve?", Dansk Sundhedstidende, 1. april 1903.

1904 Mit System, Tillges Boghandel.

1906 "Luftbade og Solbade", in: Frode Sadolin, ed., Sommerbogen, Dansk Sundhedstidendes Forlag.

1908 Kønsmoral og Livslykke, Tillges Boghandel.

1914 My Breathing System, Athletic Publications.

Müller, Mogens

2013 Det Teologiske Fakultet $i$ den 20. århundrede. En skitse, Det Teologiske Fakultet, Københavns Universitet.

Müller, Mogens \& Müller, Lisbet Kjær 
2014 Bibelleksikon, Bibelselskabets Forlag.

Nietzsche, Friedrich

1884 Der Wille zur Macht, bd. 1., Alfred Kröner Verlag.

1887 Zur Genealogie der Moral, C. G. Naumann.

Poulsen, V. A.

1884 Vore Usynlige Fjender - En Almenfattelig Skildring af Bakterierne Og Deres Forhold Til Forraadnelse, Gaering Og Smitsomme Sygdomme, Steen.

Pedersen, Mikkel Venborg

2018 Den perfekte gentleman - Mænd, stil og idealer i verden af $i$ går, Gads Forlag.

Rosenbeck, Bente

1992 Kroppens politik, Museum Tusculanum.

Rousseau, Jean-Jacques

1897 Emil eller om Opdragelse, Jydsk Forlags-Forretning.

Sadolin, Jørgen T.

1906 "Badets betydning for sjælelig renhed", Gymnastisk Selskabs Årsskrift.

Scharling, Henrik

1896 [1885-86] Christelig Sædelære efter evangelisk-luthersk Opfattelse, 1-2, Gad.

Schilling, Heinz

2014 Martin Luther - Rebel i en oprørstid, Kristeligt Dagblads forlag.

Singleton, Mark

2010 Yoga Body - the Origins of Modern Posture Practice, Oxford University Press.

https://doi.org/10.1093/acprof:oso/9780195395358.001.0001

Sloterdijk, Peter

2011 Du musst dein Leben ändern: über Anthropotechnik, Suhrkamp.

Sturm, Saverio

2015 L'architettura dei Carmelitani Scalzi in età barocca, Gangemi Editore.

Troels-Lund

1898 Dagligt Liv i Norden i det 16. Aarhundrede, bind 13, Gyldendal.

Wolbert, Klaus

2001 “Entwürfe zur Neugestaltung von Leben und Kunst um 1900", Häußer.

Zweiniger-Bargielowska, Ina

2015 "The Culture of the Abdomen: Obesity and Reducing in Britain, 1900-1939", Journal of British Studies 44 (2), 239-273. https://doi.org/10.1086/427124

Hans Bonde, professor, ph.d. E dr.phil.

Institut for idræt og ernæring, Københavns Universitet 